\title{
Effects of dietary energy and nitrogen supplements on rumen fermentation and protozoa population in buffalo and zebu cattle
}

\author{
Raul Franzolin ${ }^{1}$, Fabrício Pini Rosales ${ }^{2}$, Weber Vilas Bôas Soares ${ }^{2}$
}

\begin{abstract}
${ }^{1}$ Departamento de Zootecnia, Faculdade de Zootecnia e Engenharia de Alimentos (FZEA), Universidade de São Paulo (USP), Pirassununga, SP.
${ }^{2}$ Agência Paulista de Tecnologia dos Agronegócios, APTA, Pólo Nordeste Paulista, Mococa, SP.
\end{abstract}

ABSTRACT - The effects were assessed of two energy sources in concentrate (ground grain corn vs. citrus pulp) and two nitrogen sources (soybean meal vs. urea) on rumen metabolism in four buffaloes and four zebu cattle (Nellore) with rumen cannula and fed in a $4 \times 4$ Latin square design with feeds containing $60 \%$ sugar cane. Energy supplements had no effect on the rumen ammonia concentration in cattle, but ground grain corn promoted higher ammonia level than citrus pulp in buffalo. Urea produced higher ammonia level than soybean meal in both animal species. On average, the buffaloes maintained a lower rumen ammonia concentration $(11.7 \mathrm{mg} / \mathrm{dL})$ than the cattle $(14.5 \mathrm{mg} / \mathrm{dL})$. Buffaloes had lower production of acetic acid than cattle $(58.7$ vs. $61.6 \mathrm{~mol} / 100 \mathrm{~mol})$ and higher of propionic acid $(27.4 \mathrm{vs} .23 .6 \mathrm{~mol} / 100 \mathrm{~mol})$. There was no difference in the butyric acid production between the buffaloes $(13.6 \mathrm{~mol} / 100 \mathrm{~mol})$ and cattle $(14.8 \mathrm{~mol} / 100 \mathrm{~mol})$ and neither in the total volatile fatty acids concentration ( 82.5 vs. $83.6 \mathrm{mM}$, respectively). The energy or nitrogen sources had no effect on rumen protozoa count in either animal species. The zebu cattle had higher rumen protozoa population $\left(8.8 \times 10^{5} / \mathrm{mL}\right)$ than the buffaloes $\left(6.1 \times 10^{5} / \mathrm{mL}\right)$. The rumen protozoa population differed between the animal species, except for Dasytricha and Charonina. The buffaloes had a lower Entodinium population than the cattle (61.0 vs $84.9 \%$, respectively) and a greater percentage of species belonging to the Diplodiniinae subfamily than the cattle (28.6 vs. $1.4 \%$, respectively). In cattle, ground corn is a better energy source than citrus pulp for use by Entodinium and Diplodiniinae. In the buffaloes, the Entodinium are favored by urea and Diplodiniinae species by soybean meal.

Key Words: citrus pulp, rumen metabolism, sugar cane, urea, volatile fatty acids

\section{Efeitos de suplementos energéticos e nitrogenados na dieta sobre a fermentação e a população de protozoários no rúmen de búfalos e bovinos zebuínos}

RESUMO - Foram avaliados os efeitos de duas fontes de energia no concentrado (grãos de milho moídos vs polpa cítrica) e duas fontes nitrogenadas (farelo de soja vs ureia) sobre o metabolismo ruminal em quatro bubalinos e quatro bovinos zebuínos (Nelore). Os animais possuíam cânulas no rúmen e foram alimentados em delineamento quadrado latino $4 \times 4$, com rações contendo $60 \%$ de cana-de-açúcar. Não houve efeitos dos suplementos energéticos na concentração de amônia ruminal em bovinos, no entanto, nos bubalinos, o milho em grão promoveu maior concentração de amônia em comparação à polpa cítrica. Em ambas as espécies animais, a ureia promoveu nível mais elevado de amônia em comparação ao farelo de soja. Em média, os bubalinos mantiveram menor concentração de amônia ruminal $(11,7 \mathrm{mg} / \mathrm{dL})$ que os bovinos $(14,5 \mathrm{mg} / \mathrm{dL})$. Os búfalos apresentaram menor produção de ácido acético em comparação aos bovinos (58,7 vs $61,6 \mathrm{~mol} / 100 \mathrm{~mol})$ e maior produção de ácido propiônico $(27,4$ vs $23,6 \mathrm{~mol} / 100 \mathrm{~mol})$. Não houve diferença na produção de ácido butírico entre búfalos $(13,6 \mathrm{~mol} / 100 \mathrm{~mol})$ e bovinos $(14,8 \mathrm{~mol} / 100 \mathrm{~mol})$ nem na concentração total de ácidos graxos voláteis $(82,5$ vs $83,6 \mathrm{mM}$, respectivamente). As fontes de energia e nitrogênio não produziram efeitos em ambas as espécies animais na contagem de protozoários no rúmen. Os zebuínos apresentaram maior população de protozoários no rúmen $\left(8,8 \times 10^{5} / \mathrm{mL}\right)$ em comparação aos búfalos $\left(6,1 \times 10^{5} / \mathrm{mL}\right)$. Com exceção de Dasytricha e Charonina, a composição da população de protozoários diferiu entre as espécies animais, uma vez que nos búfalos a população de Entodinium (61,0 vs $84,9 \%$, respectivamente) foi menor e a porcentagem de espécies da subfamília Diplodiniinae, maior que nos bovinos (28,6 vs 1,4\%, respectivamente). Em bovinos, o milho moído é uma fonte de energia melhor que a polpa cítrica para utilização pela população de Entodinium e Diplodiniinae. Em búfalos, a população de Entodinium é favorecida pela oferta de ureia, enquanto espécies de Diplodiniinae são favorecidas pelo farelo de soja.

Palavras-chave: ácidos graxos voláteis, cana-de-açúcar, metabolismo rúmen, polpa cítrica, ureia 


\section{Introduction}

Comparison of the rumen metabolism of buffalo and cattle is of scientific interest in order to understand the rumen microbial activities of these ruminant species under the same feeding conditions. According to Kamra (2005) studies on buffalo rumen microorganisms are limited, and experiments comparing cattle and buffalo on similar diets and environmental conditions are rare. Efficiency of energy and nitrogen use can be improved with a better combination of the different ingredients used to formulate the diets.

Sugar cane is a tropical roughage, poor in crude protein but high in dry matter production, whereas corn grain is an energy source widely used in ruminant feeding. Soybean meal and urea are also used as protein sources. Citrus pulp is an industrial byproduct from citrus juice extraction, mainly from oranges and lemons. It is low in protein, but highly energetic without starch as carbohydrate and rich in pectin with around 25\% dry matter (Arthington et al., 2002). Citrus pulp has good potential for use in ruminant feeding systems as an energy source, in place of corn, since some experiments have suggested that citrus pulp may not depress ruminal $\mathrm{pH}$ as much as corn grain (Villarreal et al., 2006). However, Ariza et al. (2001) observed with in vitro evaluation that neutral detergent-soluble fiber from citrus pulp can provide similar energy sources compared with starch from ground maize to support ruminal microbial growth.

Data from previous cattle research trials have indicated that true protein sources such as soybean meal are better than urea to optimize ruminal function and improve diet digestibility and animal performance (Pate et al., 1990; Kim et al., 2007).

The true role of the protozoa population in the rumen still is not clear, since wide differences occur among ruminant species, feeding systems and environmental conditions around the world. These organisms have survived in the rumen for thousands of years, in close association with bacteria and fungi. Knowledge of their function may provide a key to improving animal production and preservation of the environment. The objectives of this study were to evaluate diets with different energy sources (ground corn vs. citrus pulp) and nitrogen (soybean meal vs. urea) on the rumen metabolism and protozoa population in buffalo and zebu cattle fed on sugar cane basis and to compare the effects between these animal species.

\section{Material and Methods}

Four Mediterranean buffaloes (Bubalus bubalis) and four Nellore zebu cattle (Bos indicus) with average $470 \mathrm{~kg}$ and $446 \mathrm{~kg}$ body weight, respectively, were fitted with rumen cannulae and assigned to two Latin square (LS) designs $(4 \times 4)$, one to each animal species (buffalo and cattle). Surgery was performed by veterinary personnel to minimize the animal discomfort. The cannulas were cleaned daily and sprayed to prevent insect proliferation. All animal care followed guidelines recommended for use in animal experiments from the university committee. The animals were fed around $60 \%$ of sugar cane as roughage (DM basis) with four different concentrate feeds. The dietary treatments were arranged in a $2 \times 2$ factorial with two energy sources (grain corn and citrus pulp), two nitrogen sources (soybean meal and urea) as follows: $\mathrm{COS}$ (grain corn and soybean meal); $\mathrm{COU}$ (grain corn and urea); PUS (Citrus pulp and soybean meal); PUU (citrus pulp and urea) (Table 1). The feeds were isoproteic with an average $8.8 \%$ crude protein in the total mixed feeds. The sugar cane was harvested every two days, chopped by machine just before offering once a day in the morning ( 8 a.m.). The concentrate was spread on the sugar cane and the orts were measured every day.

The experiment had four 22-day periods, each consisting of 20 days of diet adaptation followed by 2 days of rumen fluid sampling at 0 (before feeding), 2, 4 and 8 hours after feeding to measure the concentration of volatile fatty acids (acetic, propionic and butyric) and ammonia. A 5-mL ruminal fluid sample was preserved with $1-\mathrm{mL} 25 \% \mathrm{w} / \mathrm{v}$ meta-phosphoric acid for volatile fatty acid (volatile fatty acid) analysis in gas chromatography according to Erwin et al. (1961). To measure the ammonia concentration, 2-mL of the rumen liquid sample was diluted in $1-\mathrm{mL} \mathrm{H}_{2} \mathrm{SO}_{4} 1 \mathrm{~N}$ and kept in a freezer for further analysis by colorimetric phenol-hypochlorite reaction methodology. Immediately after each sampling time, the rumen $\mathrm{pH}$ was measured with a digital $\mathrm{pH}$ meter.

Table 1 - Composition of the experimental diets

\begin{tabular}{lcccc}
\hline & \multicolumn{4}{c}{ Diet $^{1}$} \\
\cline { 2 - 5 } Ingredient & COS & COU & PUS & PUU \\
\hline & \multicolumn{4}{c}{$\%$ of DM } \\
Sugar cane & 59.6 & 58.3 & 59.8 & 58.0 \\
Dried citrus pulp & 30.9 & 40.3 & - & - \\
Corn & - & - & 31.6 & 40.8 \\
Soybean meal & 9.5 & - & 8.6 & - \\
Urea & - & 1.4 & - & 1.2 \\
\hline
\end{tabular}

${ }^{1}$ Concentrate: COS (corn and soybean meal), COU (corn and urea), PUS (citrus pulp and soybean meal), PUU (citrus pulp and urea) 
Liquid outflow rate and rumen volume were measured at each LS period. One hundred grams of polyethylene glycol 4000 were used as marker and added to the rumen, via the fistula, one hour before feeding and $50 \mathrm{~mL}$ liquid rumen samples were removed immediately before the $\mathrm{PEG}$ addition and at one hour and 24 hours after feeding. The PEG concentration in the samples was measured by the turbidimetric method according to the procedure by Hyden (1955). The liquid outflow rate was calculated by regression from the natural logarithm of PEG concentration samples and rumen volume was estimated by the total amount added to the rumen and antilogarithm of intersection regression.

Samples of rumen contents were obtained manually through the fistula, approximately $30 \mathrm{~min}$ before feeding and were fixed by diluting with an equal volume of formalin solution (18.5\% formaldehyde final concentration). Total counts and generic distribution of protozoa were made in 100 microscopic fields at a magnification of 100x according to Dehority (1993). Ciliate protozoa belonging to the Diplodiniinae subfamily (e.g. Diplodinium, Eudiplodinium, Ostracodinium, Metadinium, Enoploplastron and Polyplastron) were counted together. Briefly, one $\mathrm{mL}$ of rumen contents was pipetted with a wide-mouth pipette into a tube test and two drops of brilliant green dye $(2 \mathrm{~g}$ brilliant green and $2 \mathrm{~mL}$ glacial acetic acid diluted to $100 \mathrm{ml}$ with distilled water) were added to the test tube, mixed thoroughly and allowed to stand overnight at room temperature. Further dilutions were made with $30 \%(\mathrm{v} / \mathrm{v})$ glycerol according to the cellule concentration in the samples.

Data were analyzed using the software program Statistical Sciences Inc (2003), according to two Latin square designs with four diets, four buffaloes, four zebu cattle and four periods each. The model statement included the effects of treatment and period and the random statement contained the effect of animal species: Yijk $=\mu+\mathrm{T}_{\mathrm{i}}+\mathrm{P}_{\mathrm{j}}+\mathrm{C}_{\mathrm{k}}+\mathrm{S}_{1}+\varepsilon_{\mathrm{ijk}}$ where Yijk= the dependent variable, $\mu=$ the overall mean, $\mathrm{Ti}=$ treatment effect $\mathrm{i}$ ( $\mathrm{i}=1$ to 4$) ; \mathrm{Pj}=$ period effect $\mathrm{j}(\mathrm{j}=1$ to 4$), \mathrm{Ck}=$ animal effect $\mathrm{k}(\mathrm{k}=1$ to 4$), \mathrm{Sl}=$ effect of animal species $1(\mathrm{~s}=1$ to 2$)$, and eijk is the residual error. Orthogonal contrasts were conducted including interactions comparing the effect of energy source (corn vs. citrus pulp), nitrogen source (soybean meal vs. urea) and animal species (buffalo and cattle).

\section{Results and Discussion}

There was difference in the dry matter intake among the diets and between the buffaloes and cattle $(\mathrm{P}<0.05)$.
The average dry matter intake was $13.3 \%$ higher in the buffaloes $\left(113.9 \mathrm{~g} / \mathrm{kg}^{0.75}\right)$ than in cattle $\left(100.5 \mathrm{~g} / \mathrm{kg}^{0.75}\right)$, and the smallest difference was observed with the use of citrus pulp with urea $(6.5 \%)$ and the largest with the use of citrus pulp with soybean meal (20.5\%). Diets with ground corn provided higher dry matter intake than those with citrus pulp in both animal species.

The amount of dry matter intake was different between the buffaloes and cattle according to feeding system. Misra et al. (2002) also observed higher dry matter intake in buffaloes than in cattle $(2.24 \%$ body weight vs. $1.95 \%$ body weight) fed sorghum stover supplemented with urea, but Pradhan et al. (1997) observed that dry matter intake per unit metabolic body size was lower in buffalo than in cattle when fed wheat straw-groundnut-cake diet $(9.0 \%$ crude protein) and sole berseem hay ( $11.6 \%$ crude protein).

No difference was observed among the diets within the same animal species $(\mathrm{P}>0.05)$ in the ruminal liquid outflow rate and in the rumen volume. However, the buffaloes had higher $(\mathrm{P}<0.01)$ mean liquid outflow rate and higher rumen volume, $9.4 \% / \mathrm{h}$ and $56.2 \mathrm{~L}$, than cattle, $7.7 \% / \mathrm{h}$ and $47.2 \mathrm{~L}$, respectively. The values obtained for the buffaloes were close those observed by Soares et al. (2007) with buffaloes on sugar cane based diets of $10 \% / \mathrm{h}$ liquid outflow rate and 51.4 L rumen volume.

Citrus pulp was a better energy source than ground corn for rumen microorganisms in buffaloes, promoting a higher concentration of total volatile fatty acids ( $85.0 \mathrm{vs}$. $75.6 \mathrm{mM})$, reducing acetic acid (60.2 vs. $61.9 \mathrm{~mol} / 100 \mathrm{~mol})$ and increasing butyric acid (14.8 vs. $13.3 \mathrm{~mol} / 100 \mathrm{~mol}$ ) (Table 2). Comparing soybean meal with urea as nitrogen source, the first produced higher total volatile fatty acids ( $83.9 \mathrm{vs} .76 .9 \mathrm{mM})$, decreased acetic acid (60.3 vs. $61.8 \mathrm{~mol} /$ $100 \mathrm{~mol}$ ) and increased butyric acid (14.5 vs. $13.6 \mathrm{~mol} / 100 \mathrm{~mol})$. In cattle, citrus pulp also promoted higher total volatile fatty acid production $(87.5 \mathrm{mM})$ than ground corn $(79.9 \mathrm{mM})$, increased butyric (16.1 vs. $13.5 \mathrm{~mol} / 100 \mathrm{~mol})$, but not propionic acid (22.0 vs. $25.2 \mathrm{~mol} / 100 \mathrm{~mol})$, and increased the acetic:propionic ratio (2.86 vs. 2.47 ). The soybean meal diet increased the total volatile fatty acid production $(87.5 \mathrm{mM})$ more than urea $(79.7 \mathrm{mM})$ and propionic acid production (15.6 vs. $14.0 \mathrm{~mol} / 100 \mathrm{~mol})$.

The differences obtained in the average values for volatile fatty acids production in the rumen of buffaloes and zebu cattle fed two energy and two nitrogen sources (Table 2) did not support the findings of Ariza et al. (2001) with in vitro study, which indicated a similar effect of citrus pulp and hominy for rumen microbial growth. Barrios-Urdaneta (2003) also observed no difference in the ruminal $\mathrm{pH}$ and volatile fatty acid production in the 
rumen of sheep fed ammonia-treated straw supplemented with different barley grain and citrus pulp ratios. Thus, the carbohydrate source from citrus pulp appears to promote a different effect on ruminal fermentation depending on its use in a total mix diet and of the rumen microbes present.

Comparison of the buffaloes and cattle within each treatment showed no differences in the volatile fatty acid concentration with corn and soybean meal or corn and urea. However, citrus pulp produced difference in the fermentation pattern mainly when associated with soybean meal with lower production of acetic, butyric and acetic:propionic ratio and higher propionic acid in buffaloes than cattle with no difference in total volatile fatty acid production. The propionic acid production is a better pattern of fermentation with more efficient use of dietary feed energy because waste gases are generated in acetic and butyric acid production, mainly carbon dioxide and methane, representing a significant loss of dietary energy. So, the combination of citrus pulp and soybean meal (PUS) produced a fermentation with the highest propionic acid concentration $(30.4 \mathrm{~mol} / 100 \mathrm{~mol})$ and the lowest acetic:propionic ration (1.87) in the rumen of the buffaloes, indicating a better use of the citrus pulp as energy source associated with soybean meal as nitrogen source for the species of microorganisms producing propionic acid. On the other hand, this same effect was observed with the use of ground corn combined with soybean meal or urea in the zebu cattle. Difference in butyric acid only was observed with the use of citrus pulp with soybean meal indicating greater use of this combination by specific butyric fermentation bacteria in both the buffalo and cattle species.

There is also an important effect of the nutrient digestion sites in the animal. The starch in the corn may partially escape the rumen fermentation for enzymatic digestion to glucose in the intestine, while the carbohydrate in the citrus pulp can only be used by microbial fermentation. Similarly, the advantage of soybean meal is that it can also partially escape the rumen fermentation for subsequent enzymatic digestion to amino acids. By contrast, ammonia from urea is exclusively a nutrient for rumen bacteria. These differences need to be evaluated comparing buffalo and cattle since the digestion physiology may differ according to diverse feeding and environmental systems.

The averages of volatile fatty acids concentrations obtained with all the diets in the all sampling times showed that the buffaloes produced less acetic acid (58.7 vs. $61.6 \mathrm{~mol} / 100 \mathrm{~mol})$ and more propionic acid ( 27.4 vs. $23.6 \mathrm{~mol} / 100 \mathrm{~mol}$ ) than the cattle. No difference was observed in butyric acid production between the buffaloes $(13.6 \mathrm{~mol} / 100 \mathrm{~mol})$ and cattle $(14.8 \mathrm{~mol} / 100 \mathrm{~mol})$,

Table 2 - Ruminal pH, ammonia and volatile fatty acid concentration in buffaloes and cattle fed two different energy and nitrogen sources in the concentrate

\begin{tabular}{|c|c|c|c|c|c|c|c|c|c|c|}
\hline \multirow[b]{2}{*}{ Item } & \multicolumn{4}{|c|}{ Diet $^{1}$} & \multirow[b]{2}{*}{ Mean } & \multirow[b]{2}{*}{ SEM } & \multicolumn{4}{|c|}{ P-value ${ }^{2}$} \\
\hline & $\cos$ & $\mathrm{COU}$ & PUS & PUU & & & Diets & Energy & Nitrogen & Species \\
\hline & \multicolumn{10}{|c|}{ Buffalo } \\
\hline $\mathrm{pH}$ & $6.21 \mathrm{~b}$ & $6.53 \mathrm{a}$ & $6.15 b$ & $6.26 b$ & 6.29 & 0.04 & $<0.01$ & 0.04 & 0.06 & 0.78 \\
\hline $\begin{array}{l}\mathrm{NH}_{3}-\mathrm{N}, \mathrm{mg} / \mathrm{dL} \\
\text { Volatile fatty acids }\end{array}$ & $11.19 \mathrm{ab}$ & $15.19 \mathrm{a}$ & $8.15 b$ & $12.31 \mathrm{a}$ & 11.71 & 0.75 & $<0.01$ & 0.05 & 0.02 & 0.02 \\
\hline Total, $\mathrm{mM}$ & $77.82 \mathrm{~b}$ & $71.74 b$ & $93.85 \mathrm{a}$ & $86.66 \mathrm{a}$ & 82.52 & 1.65 & $<0.01$ & $<0.01$ & $<0.01$ & 0.59 \\
\hline \multicolumn{11}{|c|}{$\mathrm{mol} / 100 \mathrm{~mol}$} \\
\hline Acetic & $59.07 \mathrm{~b}$ & $62.15 \mathrm{a}$ & $55.91 \mathrm{~d}$ & $57.64 \mathrm{c}$ & 58.69 & 0.47 & $<0.01$ & $<0.01$ & 0.01 & 0.01 \\
\hline Propionic & $26.28 \mathrm{c}$ & $25.47 \mathrm{bc}$ & $30.37 \mathrm{a}$ & $27.54 b$ & 27.42 & 0.43 & $<0.01$ & 0.86 & 0.32 & $<0.01$ \\
\hline Butyric & $14,65 \mathrm{a}$ & $12.38 \mathrm{~b}$ & $13.72 \mathrm{ab}$ & $14.82 \mathrm{a}$ & 13.64 & 0.27 & 0.01 & $<0.01$ & 0.02 & 0.02 \\
\hline Acetate:propionate ${ }^{2}$ & $2.34 \mathrm{a}$ & $2.45 \mathrm{a}$ & $1.87 \mathrm{c}$ & $2.13 b$ & 2.20 & 0.06 & $<0.01$ & 0.58 & 0.43 & $<0.01$ \\
\hline \multicolumn{11}{|c|}{ Zebu Cattle } \\
\hline $\mathrm{pH}$ & $6.15 \mathrm{c}$ & $6.28 b$ & $6.14 \mathrm{c}$ & $6.53 \mathrm{a}$ & 6.28 & 0.04 & $<0.01$ & 0.04 & $<0.01$ & 0.78 \\
\hline $\begin{array}{l}\mathrm{NH}_{3}-\mathrm{N}, \mathrm{mg} / \mathrm{dL} \\
\text { Volatile fatty acids }\end{array}$ & $11.16 \mathrm{~b}$ & $18.24 \mathrm{a}$ & $8.58 b$ & $20.07 \mathrm{a}$ & 14.51 & 0.96 & $<0.01$ & 0.81 & $<0.01$ & 0.02 \\
\hline Total, mM & $82.71 \mathrm{~b}$ & $77.14 b$ & $92.32 \mathrm{a}$ & $82.46 b$ & 83.66 & 1.52 & $<0.01$ & $<0.01$ & $<0.01$ & 0.59 \\
\hline \multicolumn{11}{|c|}{$\mathrm{mol} / 100 \mathrm{~mol}$} \\
\hline Acetic & 60.88 & 61.77 & 61.58 & 62.24 & 61.62 & 0.48 & 0.48 & 0.35 & 0.21 & 0.01 \\
\hline Propionic & $24.26 b$ & $26.10 \mathrm{a}$ & $22.11 \mathrm{c}$ & $21.88 \mathrm{c}$ & 23.59 & 0.37 & $<0.01$ & $<0.01$ & 0.17 & $<0.01$ \\
\hline Butyric & $14.87 \mathrm{~b}$ & $12.13 \mathrm{c}$ & $16.31 \mathrm{a}$ & $15.88 \mathrm{a}$ & 14.80 & 0.24 & $<0.01$ & $<0.01$ & $<0.01$ & 0.02 \\
\hline Acetate:propionate ${ }^{2}$ & $2.55 \mathrm{~b}$ & $2.38 \mathrm{~b}$ & $2.83 \mathrm{a}$ & $2.90 \mathrm{a}$ & 2.67 & 0.08 & $<0.01$ & $<0.01$ & 0.57 & $<0.01$ \\
\hline
\end{tabular}

${ }_{1}^{1}$ Concentrates: COS (corn and soybean meal), COU (corn and urea), PUS (citrus pulp and soybean meal), PUU (citrus pulp and urea).

2 All diets; energy source = corn vs. pulp citrus; nitrogen source = soybean meal vs. urea; animal species= buffalo vs. Zebu cattle.

On a line, means without a common uppercase letter differ according to $\mathrm{P}$ values shown in the treatment column. 
nor in the total volatile fatty acid concentration $(82.5$ vs. $83.7 \mathrm{mM}$. respectively). The buffaloes reached the peak of individual volatile fatty acid productions 4 hours after feeding, except for propionic acid (2 hours), whereas in cattle, the maximum concentration was observed 2 hours after feeding. Of particular interest is the different pattern of dietary carbohydrate fermentation from the citrus pulp observed between the buffaloes and cattle with the two nitrogen sources. In citrus pulp with soybean meal, the differences observed in propionic acid production between both animal species occurred only 4 and 8 hours after feeding and with the combination of citrus pulp with urea only 2 hours after feeding. Thus there was a different metabolic use by the microorganism population in the buffalo rumen compared to cattle in which there was greater use of citrus pulp by buffalo specific rumen bacteria as energy source, and urea supplied a fast nitrogen source for the microorganisms.

Daily ruminal ammonia production was different among the diets, between the sources of energy and nitrogen between the animal species, except for energy source in cattle $(\mathrm{P}=0.81)$, as well as between buffalo and cattle (Table 2). As expected, urea produced higher rumen ammonia concentration than soybean meal in both animal species. However, citrus pulp promoted lower ammonia concentration than ground grain corn in buffalo rumen liquidr (10.2 vs. $13.2 \mathrm{mg} / \mathrm{dL}$, respectively), suggesting a better $\mathrm{N}$ input to microorganisms for protein synthesis with the citrus pulp energy source.

In general, there was lower average ammonia concentration in the buffalo rumen liquid rumen $(11.7 \mathrm{mg} / \mathrm{dL})$ than in the cattle (14.5 mg/dL) (Table 2). Assis et al. (2004) did not observe changes in ammonia production and ruminal $\mathrm{pH}$ in lactating cows fed total mixed feeds with corn meal replaced with pelleted citrus pulp $(0,33,67$ and $100 \%)$ in the concentrate.

Ruminal pH was different among the diets, energy and nitrogen sources, but not between the buffaloes and cattle $(\mathrm{P}=0.78)$. Citrus pulp promoted lower $\mathrm{pH}$ than grain corn in the buffaloes ( 6.20 vs. 6.37$)$ contrasting with that in cattle (6.33 vs. 6.22). However, urea produced higher ruminal $\mathrm{pH}$ than soybean meal in the buffaloes $(6.40$ vs. 6.18$)$ and cattle (6.41 vs. 6.14).

Differences were found in rumen $\mathrm{pH}$ due the energy and nitrogen sources but not between animal species (Table 2). Franzolin et al. (2000) did not observe changes in rumen $\mathrm{pH}$ of buffalo fed with grass hay and different levels of citrus pulp in the place of corn grain in the concentrate, suggesting that there may be different effects of citrus pulp on rumen $\mathrm{pH}$, depending on the roughage source.

There was significant difference among the diets in the total number of ciliates in the buffalo rumen, but no effect of separate energy or nitrogen sources were observed (Table 3). The total ciliate population was favored by mixed feed of citrus pulp with urea $\left(7.8 \times 10^{5} / \mathrm{mL}\right)$ and with corn grain with soybean meal $\left(6.3 \times 10^{5} / \mathrm{mL}\right)$. In the cattle, there was no effect of treatment, energy or nitrogen sources on the total rumen protozoa population. No Epidinium species were found in the rumen of the cattle.

There was no effect of diets or energy source on the generic composition in the rumen ciliate population in the buffaloes. In the cattle, there were significant differences among the treatments in the generic distribution of Entodinium, Dasytricha and Charonia (Table 3). Relevant differences were observed in the influence of the energy and nitrogen sources on the rumen ciliate composition of protozoa of the Entodinium genus and ciliates of the subfamily Diplodiniinae according to different ruminant species, buffalo or zebu cattle. No difference was found in the buffaloes regarding the energy source, but urea promoted a higher percentage of Entodinium and lower percentage of Diplodiniinae (70.6 and $20.4 \%$, respectively) than soybean meal (51.4 and $36.6 \%$ ). Javaid et al. (2008) observed in buffalo that dietary rumen degradable protein had a quadratic effect on the total bacterial and protozoa count with maximum microbial count at $82 \%$ rumen degradable protein. In zebu cattle, no difference was observed with nitrogen source, but ground corn promoted a higher percentage of Entodinium and Diplodiniinae $(90.6 \%$ and $2.0 \%$, respectively) than citrus pulp (79.1 and $0.7 \%$ ). These data were different from previous research (Franzolin et al., 2000) with buffaloes fed grass hay as roughage, mixed with ground corn and citrus pulp in the concentrate, that promoted a greater proportion of ciliate protozoa belonging to the Diplodiniinae subfamily than Entodinium species, but the inverse occurred when the concentrate was composed exclusively of corn grain or citrus pulp, which indicated relevant modification of the rumen microbial population according to energy source associated with roughage source.

The buffaloes had a lower Entodinium composition and a higher composition of species belonging to the Diplodiniinae subfamily (61.0 and $28.6 \%$, respectively) than the cattle ( 84.9 and $1.4 \%$ ). In general, the Entodinium species represent more than $80 \%$ of the population for most domestic ruminants even under grazing conditions (Dehority, 2003). 
Table 3 - Total concentration and generic distribution of rumen ciliate protozoa in buffaloes and cattle fed different nitrogen and energy sources in concentrate

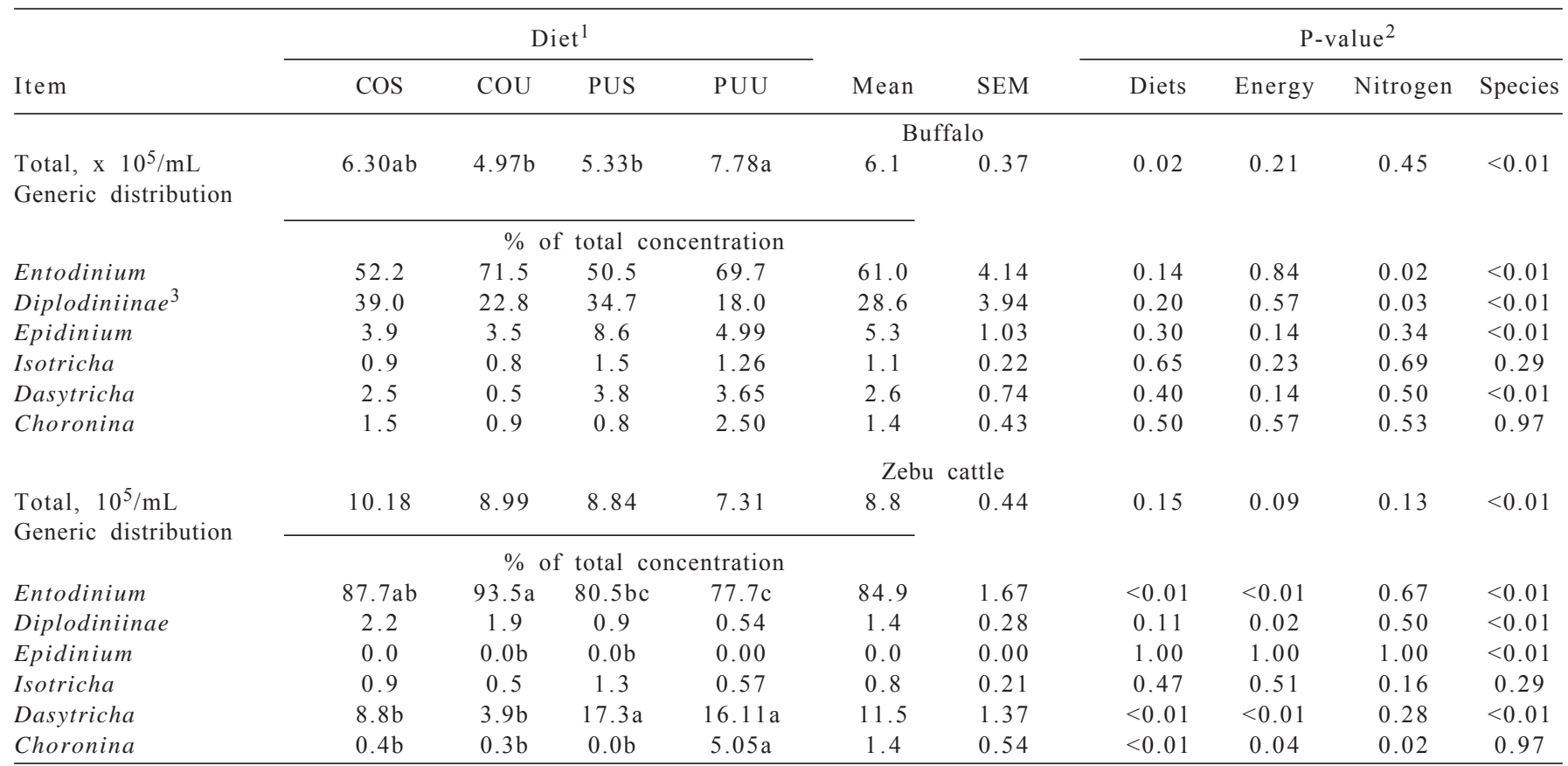

${ }^{1}$ Concentrates: COS (corn and soybean meal), COU (corn and urea), PUS (citrus pulp and soybean meal), PUU (citrus pulp and urea).

2 All diets; Energy source = corn vs. pulp citrus; nitrogen source = soybean meal vs. urea; animal species = Buffalo vs. Zebu cattle.

${ }^{3}$ Subfamily, including the genera Diplodinium, Eudiplodinium, Ostracodinium, Metadinium, Enoploplastron and Polyplastron.

On a line, means without a common uppercase letter differ according to $P$ values showed in the Treatment column.

The zebu cattle had higher numbers of rumen protozoa in all treatments (mean $8.8 \times 10^{5} / \mathrm{mL}$ ) than the buffaloes (mean $6.1 \times 10^{5} / \mathrm{mL}$ ), except for citrus pulp with urea (Table 3). The mean rumen $\mathrm{pH}$ was similar between both animal species but the buffaloes had a higher liquid outflow rate that could be involved in a lower number of total rumen ciliate protozoa (Dehority, 2003). These data were in agreement with Wanapat et al. (2000) who observed lower rumen protozoal populations in swamp buffalo with lower numbers of holotrichs (Isotricha and Dasytricha) and entodiniomorphs compared to those in cattle raised under traditional village conditions in the northeast of Thailand. However, Kumar et al. (2002) observed higher concentration of total protozoa in buffalo $\left(9 \times 10^{5} / \mathrm{mL}\right)$ than in cattle rumen $\left(6 \times 10^{5} / \mathrm{mL}\right)$ fed an oaten-hay-concentrate.

Interesting findings also were observed with the Dasytricha composition in the rumen of cattle where citrus pulp promoted 2.6 times more percentage (16.7\%) than corn grain $(6.4 \%)$. Usually, cattle on diets based on sugar cane maintain high percentages of holotricha ciliates in the rumen (Valdez et al., 1977; Fernandez et al., 1980; Leng et al., 1981; Valvasori et al., 2001) because these species are able to ferment many simple carbohydrates (Dehority, 2003). There was higher Dasytricha composition in the rumen ciliate population in the cattle (mean $11.5 \%$ ) than in the buffaloes (mean 2.6\%). This fact allows postulation of a possible a growth control of Holotricha species by ciliates of Epidinium and/or Diplodiniinae species by competition for nutrient sources in the rumen. Therefore, in reduced of Epidinium composition and/or species belonging to the Diplodiniinae subfamily, Dasytricha is benefitted by citrus pulp as energy source. These findings should be clarified for further investigations.

The data showing a higher concentration of rumen ciliate protozoa species belonging to the Diplodiniinae subfamily in the buffaloes $(28.6 \%)$ than in the cattle $(1.4 \%)$ confirmed other findings that ruminal composition of the ciliate protozoa population in buffaloes is different from cattle fed with different types of feed, especially in the proportion Entodinium:Diplodiniinae (Franzolin \& Dehority, 1999; Franzolin \& Franzolin, 2000). Singh et al. (2003) also observed that ciliates of the Eudiplodinium genus were more than three times higher in buffaloes $(2.1 \%)$ compared to cattle $(0.6 \%)$ fed on wheat strawpreformed protein diets.

\section{Conclusions}

Data from the buffaloes and cattle fed sugar cane as roughage shows that citrus pulp is a suitable substitute for corn grain as an energy source, promoting a better rumen fermentation pattern in the buffaloes when 
combined with both sources of nitrogen, soybean meal or urea, and in cattle with soybean meal alone. The buffaloes produce a lower acetic:propionic ratio at the same total volatile fatty acids concentration than the zebu cattle and they have a lower total number of ciliate/mL rumen content with a lower percentage of Entodinium and higher percentage of species belonging to the Diplodiniinae subfamily. In the cattle, ground corn is a better energy source than citrus pulp for use by the Entodinium and Diplodiniinae species, whereas in the buffaloes, the Entodinium species are favored with urea and Diplodiniinae with soybean meal.

\section{References}

ARIZA, P.; BACH, A.; STERN, M.D. et al. Effects of carbohydrates from citrus pulp and hominy feed on microbial fermentation in continuous culture. Journal of Animal Science, v.79, p.2713-2718, 2001.

ARTHINGTON, J.D.; KUNKLE, W.E.; MARTIN, A.M. Citrus pulp for cattle. Veterinary Clinics North America-Food Animal Practice, v.18, p.317-326, 2002.

ASSIS, A.J.; CAMPOS, J.M.D.; QUEIROZ, A.C. et al. Polpa cítrica em dietas de vacas em lactação. 2. digestibilidade dos nutrientes em dois períodos de coleta de fezes, ph e nitrogênio amoniacal do líquido ruminal. Revista Brasileira de Zootecnia, v.33, p.251-257, 2004.

BARRIOS-URDANETA, A.; FONDEVILA, M.; CASTRILLO, C. Effect of supplementation with different proportions of barley grain or citrus pulp on the digestive utilization of ammoniatreated straw by sheep. Animal Science, v.76, p.309-317, 2003.

DEHORITY, B.A. Rumen microbiology. Thrumpton: Nottingham University Press, 2003. 372p.

DEHORITY, B.A. Laboratory manual for classification and morphology of rumen ciliate protozoan. Boca Raton: CRC Press, 1993. 96p.

ERWIN, E.S.; MARCO, G.J.; EMERY, E.M. Volatile fatty acid analyses of blood and rumen fluid by gas chromatography. Journal of Dairy Science, v.44, p.1768-1771, 1961.

FERNANDEZ, A.; GILL, M.; DONE, F. et al. Studies on the rumen fermentation pattern in cattle receiving diets based on chopped whole sugar cane or sugar cane juice. Tropical Animal Production, v.5, p.288-289, 1980.

FRANZOLIN, R.; DEHORITY, B.A. Comparison of protozoal populations and digestion rates between water buffalo and cattle fed an all forage diet. Journal Applied of Animal Research, v.16, p.33-46, 1999.

FRANZOLIN, R.; FRANZOLIN, M.H.T. População protozoários ciliados e degradabilidade ruminal em búfalos e bovinos zebuínos sob dieta à base de cana-de-açúcar. Revista Brasileira de Zootecnia, v.29, p.1853-1861, 2000.

FRANZOLIN, R.; FRANZOLIN, M.H.T.; COMIDE, C.A. et al. Efeitos de dietas com polpa cítrica em substituição ao milho em grãos no concentrado sobre a degradabilidade e a fauna ruminal em bubalinos. Revista Brasileira de Zootecnia, v.29, p.2109-2118, 2000.
HYDEN, S. A turbidimetric method for the determination of higher polyethylene glycols in biological materials. Kungl Lanthbrukshogskolans Annaler, v.22, p.139-145, 1955.

JAVAID, A.; MAHR-UN-NISA; SARWAR, M. et al. Ruminal characteristics, blood $\mathrm{pH}$, blood urea nitrogen and nitrogen balance in Nili-ravi buffalo (Bubalus bubalis) bulls fed diets containing various levels of ruminally degradable protein. Asian-Australasian Journal of Animal Sciences, v.21, p.51-58, 2008 .

KAMRA, D.N. Rumen microbial ecosystem. Current Science, V. 89, p.124-135, 2005.

KIM, S.C.; ADESOGAN, A.T.; ARTHINGTON, J.D. Optimizing nitrogen utilization in growing steers fed forage diets supplemented with dried citrus pulp. Journal of Animal Science, v.85, p.2548-2555, 2007.

KUMAR, S.; SINGH, S.; BHATIA, S.K. et al. Microbial and biochemical changes in the rumen of cattle and buffalo fed oat hay-concentrate diet. Indian Journal of Animal Nutrition, v.19, p.78-80, 2002.

LENG, R.A.; GIL, M.; KEMPTON, T.J. et al. Kinetics of large ciliate protozoa in the rumen of cattle given sugar-cane diets. British Journal of Nutrition, v.46, p.371-384, 1981.

MISRA, A.K.; SINGH, A.P.; MAITY, S.B. et al. Effect of feeding urea impregnated sorghum stover haylage and dry sorghum stover supplemented with urea on cattle and buffalo. Range Management and Agroforest, v.23, p.158-160, 2002.

PATE, F.M.; SANSON, D.W.; MACHEN, R.V. Value of a molasses mixture containing natural protein as a supplement to brood cows offered low-quality forages. Journal of Animal Science, v.68, p.618-623, 1990 .

PRADHAN, K.; BHATIA, S.K.; SANGWAN, D.C. Feed consumption pattern, ruminal degradation, nutrient digestibility and physiological reactions in buffalo and cattle. Indian Journal of Animal Science, v.67, p.149-151, 1997.

SINGH, S.; BHATIA, S.K.; PRADHAN, K. Relative ruminal ciliates distribution and physiology of bacteria isolated in buffalo and cattle fed wheat straw-preformed protein diets. Indian Journal of Animal Science, v.73, p.663-667, 2003.

STATISTICAL SCIENCES INC. S-PLUS for Windows User's Manual, V.5.5: Seattle, 2003.

SOARES, W.V.B.; FRANZOLIN, R.; SOUZA, N.H. Effect of addition of different strains of yeast (Saccharomyces cerevisae) on liquid phase outflow rate, ruminal volume and in situ degradability in buffaloes fed on sugar cane basis. Italian Journal of Animal Science, v.6 (Supl. 2), p.536-539, 2007.

VALDEZ, R.E.; ALVAREZ, F.J.; FERREIRO, H.M. et al. Rumen function in cattle given sugar cane. Tropical Animal Production, v.2, p.260-272, 1977

VALVASORI, E.; LAVEZZO, W.; LUCCI, C.S. et al. Alterações na fermentação ruminal de bovinos fistulados alimentados com cana-de-açúcar em substituição à silagem de milho. Boletim da Indústria Animal, v.58, p.35-45, 2001.

VILLARREAL, M.; COCHRAN, R.C.; ROJAS-BOURRILLON, A. et al. Effect of supplementation with pelleted citrus pulp on digestibility and intake in beef cattle fed a tropical grassbased diet (Cynodon nlemfuensis) Animal Feed Science and Technology, v.125, p.163-173, 2006.

WANAPAT, M.; NGARMSANG, A.; KORKHUNTOT, S. et al. A comparative study on the rumen microbial population of cattle and swamp buffalo raised under traditional village conditions in the northeast of Thailand. Asian-Australasian Journal of Animal Science, v.13, p.918-921, 2000. 